\title{
Pengaruh Profitabilitas terhadap Nilai Perusahaan dengan Kebijakan Deviden sebagai Variabel Intervening
}

\author{
DWI ATMIKASARI \\ IIN INDARTI \\ ELMAMUNCAR ADITYA \\ Sekolah Tinggi Ilmu Ekonomi Widya Manggala \\ Jalan Sriwijaya No.32 \& 36 Semarang 50242 \\ Email: dwi.atmikasari@gmail.com
}

Diterima 17 Desember 2019; disetujui 27 Desember 2019;

\begin{abstract}
This study aimed to determine the effect of profitability on firm value through dividend policy as the intervening variable. The population and sample used were 37 companies listed in Indonesia stock exchange for 3 years (2015-2017). The sampling technique used was non-random sample using non-probability technique with a method based on saturated sampling. The analytical tool used was path analysis test which waspreviously tested by descriptive test, classical assumption test and hypothesis test. The results of the study indicated that profitability $(X)$ had a positive and significant effect on firm value $(Y)$. Profitability $(X)$ had a positive and significant effect on dividend policy $(Z)$. Dividend policy $(Z)$ had a positive and significant effect on firm value $(Y)$. Profitability $(X)$ had a positive and significant effect on firm value $(Y)$ through dividend policy $(Z)$ as the intervening variable. The result of determination coefficient $\left(R^{2}\right)$ is $0,500 \%$. It means the influence of profitability and dividend policy on firm value as much as 50\%. While the remaining 50\% is influenced by other variables outside the variables studied.
\end{abstract}

Keywords: Profitability, dividend policy, firm value

\section{PENDAHULUAN}

Latar Belakang. Perusahaan sebagai entitas ekonomi lazimnya memiliki tujuan jangka pendek dan jangka panjang. Dalam jangka pendek perusahaan bertujuan memperoleh laba secara maksimal dengan menggunakan sumber daya yang ada, sementara dalamjangka panjang tujuan utama perusahaan adalah memaksimalkan nilai perusahaan. Afifatul,dkk (2017) menyatakan bahwa nilai perusahaan yang tinggi akan diikuti oleh tingginya kemakmuran pemegang saham. Nilai perusahaan yang tinggi juga menunjukkan kinerja perusahaan yang baik.

Menurut Brigham dan Houston (2015), terdapat beberapa faktor yang mempengaruhi nilai perusahaan, yaitu : rasio likuiditas, rasio manajemen aktiva, rasio manajemen utang, dan rasio profitabilitas

Menurut Sujoko dan Soebiantoro (2007), Profitabilitas menjadi pertimbangan yang cukup penting bagi investor dalam keputusan investasi. Profitabilitas yang tinggi menunjukan prospek perusahaan yang baik sehingga investor akan merespon positif sinyal tersebut dan nilai perusahaan akan meningkat.

Kebijakan deviden suatu perusahaan dinilai oleh investor sebagai tolok ukur dalam memperoleh laba. Semakin besar laba bersih yang dihasilkan oleh perusahaan, semakin besar pula deviden yang akan dibagikan kepada pemegang saham. Hal ini menjadi ketertarikan investor untuk melakukan investasi atau menanamkan modalnya pada perusahaan yang mampu menghasilkan laba bersih yang besar dan 
terus meningkat (Hadiyanti, 2014).

Berdasarkan penjelasan diatas beserta dengan beberapa penelitian terdahulu peneliti menggunakan perusahaan manufaktur. Perusahaan manufaktur adalah perusahaan industri pengolahan yang mengolah bahan baku menjadi barang setengah jadi atau barang jadi. Menperin meyakini industri manufaktur masih menjadi kontributor terbesar bagi perekonomian nasional diantaranya melalui peningkatan pada nilai tambah bahan baku dalam negeri, penyerapan tenaga kerja lokal dan penerimaan devisa dari ekspor (www.bps.go.id). Pertumbuhan positif yang dialami oleh perusahaan manufaktur yang ada di Indonesia menjadi sektor bisnis yang cukup menguntungkan karena pangsa pasar perusahaan manufaktur ini besar dan berpotensi berkembang terus. Oleh karena itu terjadi persaingan yang semakin kuat antar sesama perusahaan manufaktur di Indonesia. Persaingan yang ketat menyebabkan perusahaan manufaktur perlu memaksimalkan pemanfaatan seluruh sumber daya demi mempermudah perusahaan untuk mencapai tujuannya.

Tujuan Penelitian. Tujuan penelitian ini adalah menganalisis pengaruh profitabilitas terhadap nilai perusahaan dengan kebijakan deviden sebagai variabel intervening pada perusahaan manufaktur yang terdaftar pada BEI periode tahun 2015-2017.

\section{TINJAUAN TEORETIS}

Teori Keagenan. Dalam manajemen keuangan, tujuan dari perusahaan adalah memaksimumkan kemakmuran pemegang saham yang diterjemahkan sebagai memaksimumkan harga saham. Tetapi dalam kenyataannya tidak jarang manager memiliki tujuan lain yang mungkin bertentangan dengan tujuan utama tersebut. Karena manager diangkat oleh pemegang saham maka idealnya mereka akan bertindak on the best of interest of stockholders, tetapi dalam praktek sering terjadi konflik. Konflik kepentingan antar agen sering disebut dengan agency problem. Hubungan antar agen terjadi pada saat satu orang atau lebih - disebut principals mengangkat satu atau lebih orang lain - disebut agen - untuk bertindak atas nama pemberi wewenang dan memberikan kekuasaan dalam pengambilan keputusan. Agency problem biasanya terjadi antara manajer dan pemegang saham atau antara debtholders dan stockholders. (Sartono, 2014).

Signalling Theory. Signalling Theory merupakan suatu tindakan yang diambil perusahaan untuk memberikan petunjuk bagi investor tentang bagaimana manajemen memandang prospek perusahaan (Brigham, 2008). Signalling theory menekankan kepada pentingnya informasi yang dikeluarkan oleh perusahaan terhadap keputusan investasi pihak diluar perusahaan. Informasi merupakan unsur penting bagi investor dan pelaku bisnis karena informasi pada hakikatnya menyajikan keterangan, catatan atau gambaran baik untuk keadaan masa lalu, saat ini maupun keadaan pada masa yang akan datang bagi kelangsungan hidup suatu perusahaan dan bagaimana efek pasarannya. Informasi yang lengkap, relevan, akurat dan tepat waktu diperlukan oleh investor dipasar modal sebagai alat analisis untuk mengambil keputusan investasi. Informasi yang dipublikasikan sebagai suatu pengumuman akan memberikan signal baik bagi investor dalam pengambilan keputusan investasi .jika pengumunan mengandung nilai positif, makan diharapkan pasar akan bereaksi pada waktu pengumuman tersebut diterima oleh pasar (Jogiyanto, 2000).

Bird in The Hand Theory. Teori bird in the hand adalah teori yang menjelaskan bahwa investor menghendaki pembayaran deviden yang tinggi. Myron Gordon dan John Lintner yang berpendapat bahwa Ks akan turun apabila rasio pembagian deviden dinaikkan karena para investor kurang yakin terhadap penerimaan keuntungan modal (capital gains) yang akan dihasilkan dari laba yag ditahan dibandingkan dengan seandainya mereka menerima deviden. Gordon dan Lintner berkata bahwa sesungguhnya investor jauh lebih menghargai pendapatan yang diharapkan dari deviden daripada pendapatan yang diharapkan dari keuntungan modal karena komponen hasil deviden, D1/P0 resikonya lebih kecil daripada komponen g dalam persamaan total pengembalian yang diharapkan, Ks $=\mathrm{D} 1 / \mathrm{P0}+\mathrm{g}$ (Brigham dan Houston, 1999).

Nilai Perusahaan. Nilai perusahaan merupakan kinerja perusahaan yang dicerminkan oleh harga saham yang dibentuk oleh permintaan dan penawaran di pasar modal yang merefleksikan 
penilaian masyarakat terhadap kinerja perusahaan (Harmono,2009). Semakin tinggi harga saham, maka makin tinggi kemakmuran pemegang saham untuk mencapai nilai perusahaan umumnya para pemodal menyerahkan pengelolaannya kepada para profesional. Samuel (2001) dalam Dwianika (2018) menjelaskan bahwa enterprise value (EV) atau dikenal juga sebagai firm value (nilai perusahaan) merupakan konsep penting bagi investor, karena merupakan indikator bagi pasar menilai perusahaan secara keseluruhan.

Nilai perusahaan dapat diukur menggunakan EPS, PER, PBV dan volume perdagangan saham. Dalam penelitian ini, nilai perusahaan diproksikan dengan PBV (Price Book Value) atau rasio harga per nilai buku, menurut Brigham dan Gapenski (1999), PBV (Price Book Value) yaitu nilai yang diberikan pasar keuangan kepada manajemen dan organisasi perusahaan sebagai sebuah perusahaan yang terus tumbuh.

Kebijakan Deviden. Deviden adalah bagian laba usaha yang diperoleh perusahaan kepada pemegang sahamnya sebagai imbalan atas kesediaan mereka menanamkan hartanya dalam perusahaan (Rudianto, 2012 dalam Afifatul, dkk, 2017). Perusahaan yang mampu memberikan deviden tinggi akan mendapat kepercayaan dari investor. Deviden tinggi membuat investor tertarik, sehingga akan terjadi peningkatan terhadap permintaan saham. Tingginya permintaan saham membuat para investor menghargai nilai saham lebih besar dari yang tertera pada neraca perusahaan, sehingga nilai perusahaan juga akan tinggi (Afifatul, dkk, 2017).

Kebijakan deviden adalah keputusan apakah laba yang diperoleh perusahaan akan dibagikan kepada pemegang saham sebagai deviden atau akan ditahan dalam bentuk laba ditahan guna pembiayaan innvestasi dimasa datang (Sartono, 2014).

Proporsi Net Income After Tax yang dibagikan sebagai deviden biasanya diproksikan dalan Devidend Pay Out Ratio (DPR). Devidend Pay Out Ratio inilah yang menentukan besarnya deviden per lembar saham (Devidend Per Share). Jika deviden yang dibagikan besar maka hal tersebut akan meningkatkan harga saham yang juga berakibat pada peningkatan dari nilai perusahaan (Arindita, 2015).
Profitabilitas. Profitabilitas adalah hasil akhir dari sejumlah kebijakan dan keputusan yang dilakukan oleh perusahaan. Rasio-rasio yang telah dibahas sejauh ini dapat memberikan petunjukpetunjuk yang berguna dalam menilai keefektifan dari operasi sebuah perusahaan, tetapi rasio profitabilitas (profitability ratio) akan menunjukkan kombinasi efek dari likuiditas, manajemen aktiva, dan utang pada hasil-hasil operasi ( Brigham\& Houston, 2015). Semakin baik pertumbuhan profitabilitas perusahaan berarti prospek perusahaan di masa depan dinilai semakin baik, artinya nilai perusahaan juga akan dinilai semakin baik dimata investor. Apabila kemampuan perusahaan untuk menghasilkan laba dalam jangka panjang meningkat maka nilai perusahaan juga akan meningkat dan akan tercermin pada harga sahamnya (Aditya dan Supriyono, 2015).

Besarnya tingkat laba akan mempengaruhi besarnya tingkat pembayaran dividen yang dibagikan kepada pemegang saham (Idawati dan Sudiartha,2014) dalam Kherismawati, dkk (2017). Profitabilitas juga mencerminkan keadaan posisi keuangan perusahaan. Hal ini menjadi perhatian utama investor dalam mengukur laba atas investasi yang dilakukan (Kadumi dan Al-Kilanni, 2015) dalam Kherismawati, dkk (2017). Rasio profitabilitas, dapat mengukur seberapa besar kemampuan perusahaan memperoleh laba baik dalam hubungannya dengan penjualan, assets maupun laba bagi modal sendiri (Sartono, 2014).

Penelitian Terdahulu. Penelitian mengenai pengaruh profitabilitas terhadap nilai perusahaan dengan kebijakan dividen sebagai variabel intervening telah banyak dilakukan di dunia. Sejauh ini hasinya masih menunjukkan keberagaman. Ringkasan penelitian terdahulu dapat dilihat pada tabel 1.

Kerangka Penelitian. Untuk memudahkan pemahaman mengenal model penelitian ini, maka disusunlah kerangka pemikiran pada Gambar 1 .

Hipotesis. Berdasarkan landasan teoretis dan beberapa penelitian terdahulu, maka hipotesis dalam penelitian ini adalah sebagai berikut:

H1 : Profitabilitas berpengaruh positif terhadap nilai perusahaan pada perusahaan manufaktur yang terdaftaf di BEI periode 2015-2017.

H2 : Profitabilitas berpengaruh positif terhadap 


\section{Gambar 1 \\ Kerangka Penelitian}

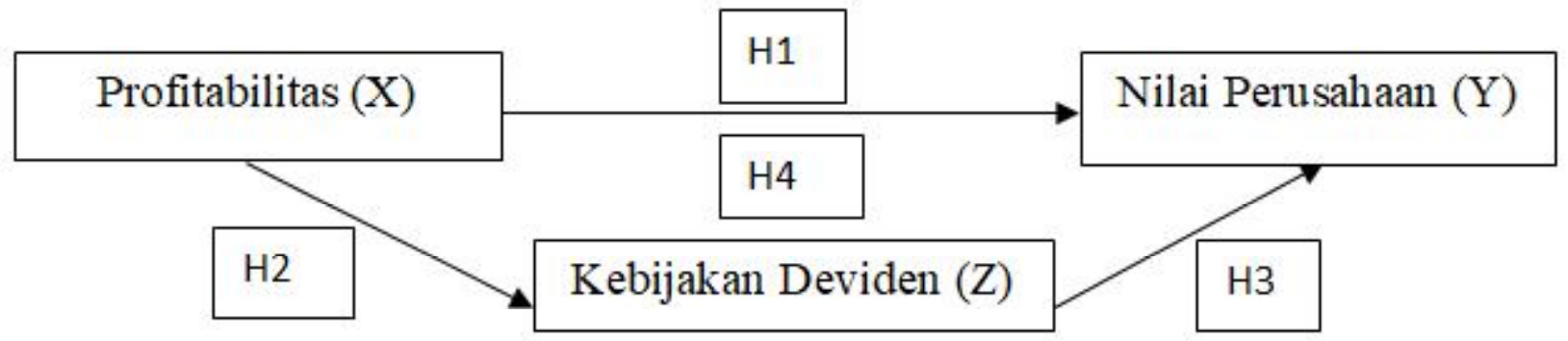

Sumber : Review Jurnal 2019

Tabel 1

Ringkasan Hasil Penelitian Terdahulu

\begin{tabular}{lll}
\hline No & Peneliti (Tahun) & \multicolumn{1}{c}{ Variabel } \\
\hline 1 & Indriawati, dkk, & X1 : Profitabilitas \\
& 2018 & X2 : Keputusan Investasi \\
& & X3 : Pertumbuhan Perusahaan \\
& & Y1 : Kebijakan Deviden \\
& & Y2 : Nilai Perusahaan
\end{tabular}

2 Sustari $\mathrm{X}$ : Profitabilitas

Alamsyah, 2017 Y1 : Relevansi Nilai Informasi Akuntansi

Y2 : Keputusan Investasi

Y3 : Kebijakan Deviden

Y2 : Nilai Perusahaan
- Profitabilitas dan keputusan investasi berpengaruh positif dan signifikan terhadap nilai perusahaan

- Pertumbuhan perusahaan tidak berpengaruh signifikan terhadap nilai perusahaan

- Profitabilitas berpengaruh positif dan signifikan terhadap kebijakan deviden

- Keputusan investasi dan pertumbuhan perusahaan tidak berpengaruh signifikan terhadap kebijakan deviden

- Kebijakan deviden tidak berpengaruh signifikan terhadap nilai perusahaan.

- Profitabilitas yang berpengaruh signifikan terhadap nilai perusahaan

- Profitabilitas berpengaruh positif signifikan terhadap kebijakan deviden

- Kebijakan deviden mempunyai pengaruh positif tidak signifikan terhadap nilai perusahaan

- Variable relevansi nilai informasi akuntansi, kesempatan investasi dan kebijakan deviden belum mampu menjadi variable intervening didalam menunjang pengaruh antara profitabilitas terhadap nilai perusahaan

\begin{tabular}{|c|c|c|c|}
\hline 3 & $\begin{array}{l}\text { Fadli Ali Taslim, } \\
2016\end{array}$ & $\begin{array}{l}\text { X1 : Rasio Likuiditas } \\
\text { X2 : Rasio Aktifitas } \\
\text { X3 : Profitabilitas } \\
\text { Y1 : Kebijakan Deviden } \\
\text { Y2 : Nilai Perusahaan } \\
\end{array}$ & $\begin{array}{l}\text { - Variable profitabilitas yang diproksikan dengan ROE tidak } \\
\text { berpengaruh terhadap nilai perusahaan } \\
\text { - Variable profitabilitas yang diproksikan dengan ROE ini } \\
\text { berpengaruh positif terhadap nilai perusahaan melalui } \\
\text { kebijakan deviden sebagai variabel intervening }\end{array}$ \\
\hline 4 & $\begin{array}{l}\text { Dinda Aditya } \\
\text { dan Edy } \\
\text { Supriyono, } 2015\end{array}$ & $\begin{array}{l}\text { X1: Profitabilitas } \\
\text { X2 : Kepemilikan Institusional } \\
\text { Y1 : Kebijakan Deviden } \\
\text { Y2 : Nilai Perusahaan }\end{array}$ & $\begin{array}{l}\text { - Profitabilitas berpengaruh signifikan positif terhadap nilai } \\
\text { perusahaan } \\
\text { - Profitabilitas tidak berpengaruh signifikan positif terhadap } \\
\text { kebijakan deviden } \\
\text { - Kebijakan deviden berpengaruh secara signifikan positif } \\
\text { terhadap nilai perusahaan } \\
\text { - Kebijakan deviden belum mampu menjadi variable intervening } \\
\text { didalam menunjang pengaruh antara profitabilitas terhadap nilai } \\
\text { perusahaan. }\end{array}$ \\
\hline 5 & $\begin{array}{l}\text { Ria Nofrita, } \\
2013\end{array}$ & $\begin{array}{l}\mathrm{X}: \text { Profitabilitas } \\
\text { Y1 : Kebijakan Deviden } \\
\text { Y2 : Nilai Perusahaan }\end{array}$ & $\begin{array}{l}\text { - Profitabilitas berpengaruh positif signifikan terhadap nilai } \\
\text { perusahaan } \\
\text { - Profitabilitas tidak berpengaruh signifikan terhadap kebijakan } \\
\text { deviden } \\
\text { - Kebijakan deviden berpengaruh positif signifikan terhadap } \\
\text { kebijakan deviden } \\
\text { - Pengaruh tidak langsung menunjukkan hasil bahwa } \\
\text { profitabilitas tidak berpengaruh terhadap nilai perusahaan } \\
\text { melalui kebijakan deviden sebagai variable intervening } \\
\end{array}$ \\
\hline
\end{tabular}

Sumber: Review Penelitian (2019) 
kebijakan deviden pada perusahaan manufaktur yang terdaftaf di BEI periode 2015-2017.

H3 : Kebijakan deviden berpengaruh positif terhadap nilai perusahaan pada perusahaan manufaktur yang terdaftaf di BEI periode 2015-2017.

H4 : Profitabilitas berpengaruh positif terhadap nilai perusahaan melalui kebijakan deviden sebagai variable intervening pada perusahaan manufaktur yang terdaftar di BEI periode 2015-2017.

\section{METODE PENELITIAN}

Jenis Penelitian. Jenis penelitian ini termasuk dalam jenis penelitian kausal komparatif. Menurut Indriantoro \& Supomo (1999), penelitian kausal komparatif merupakan tipe penelitian dengan karakteristik masalah berupa hubungan sebabakibat antara dua variabel atau lebih. Dalam penelitian ini hubungan sebab aibat diasumsikan terjadi antara profitabilitas, nilai perusahaan, dan kebijakan deviden.

Definisi Operasional. Definisi operasional menjelaskan cara tertentu yang digunakan oleh peneliti dalam mengoperasikan construct, sehingga memungkinkan bagi peneliti yang lain untuk melakukan replika pengukuran dengan cara yang sama atau mengembangkan cara pengukuran construct yang lebih baik (Indriantoro dan Supomo, 1999). Adapun definisi operasional dari variabel penelitian ini adalah sebagai berikut :

\section{Nilai Perusahaan}

Nilai perusahaan adalah nilai jual sebuah perusahaan sebagai suatu bisnis yang sedang beroperasi.Adanya kelebihan nilai jual diatas nilai likuidasi adalah nilai dari organisasi manajemen yang menjalankan perusahaan itu.Dalam penelitian ini untuk mengukur nilai perusahaan dengan menggunakan Price Book Value (PBV) yaitu perbandingan antara harga per lembar saham dengan nilai buku per lembar saham. Dengan rumus sebagai berikut :

$\mathrm{PBV}=\frac{\text { Harga per lembar saham }}{\text { Nilai buku per lembar saham }} \times 100 \%$

\section{Profitabilitas}

Profitabilitas adalah hasil akhir dari sejumlah kebijakan dan keputusan yang dilakukan oleh perusahaan. Rasio-rasio yang telah dibahas sejauh ini dapat memberikan petunjuk-petunjuk yang berguna dalam menilai keefektifan dari operasi sebuah perusahaan, tetapi rasio profitabilitas (profitability ratio) akan menunjukkan kombinasi efek dari likuiditas manajemen aktiva, dan utang pada hasil-hasil operasi.

Return on equity (ROE) merupakan suatu pengukuran dari penghasilan (income) yang tersedia bagi para pemilik perusahaan (baik pemegang saham biasa maupun saham preferen) atas modal yang mereka investasikan didalam perusahaa. Variabel ini diukur dengan menggunakan rumus sebagai berikut :

$$
\text { ROE }=\frac{\text { Laba bersih setelah pajak }}{\text { Ekuitas }} \times 100 \%
$$

\section{Kebijakan Deviden}

Kebijakan deviden menentukan pembagian laba antara pembayaran kepada pemegang saham dan investasi kembali perusahaan. Laba ditahan (retained earnings) merupakan salah satu sumber dana paling penting untuk membiayai pertumbuhan perusahaan, tetapi deviden merupakan arus kas yang disisihkan untuk pemegang saham.

Dalam penelitian ini, mengukur kebijakan deviden melalui Deviden Payout Ratio (DPR) yaitu perbandingan antara deviden per lembar saham dengan laba per lembar saham. Dengan rumus sebagai berikut:

$$
\text { DPR }=\frac{\text { Deviden per lembar } \text { saham }}{\text { Laba per lembar saham }} \times 100 \%
$$

Populasi. Populasi dalam penelitian ini adalah semua kelompok perusahaan manufaktur yang terdaftar di Bursa Efek Indonesia periode 20152017. Populasi perusahaan manufaktur yang terdaftar di Bursa Efek Indonesia periode 20152017 berjumlah 146 perusahaan. Dipilihnya satu kelompok industri yaitu industri manufaktur sebagai populasi karena industrimanufaktur memiliki jumlah perusahaan terbesar yang terdaftar di Bursa Efek Indonesia dan industri manufaktur terdiri dari beberapa sektor.

Sampel. Sampel ialah sebagian anggota populasi yang diambil dengan menggunakan teknik 
tertentu yang disebut dengan teknik sampling (Usman, 2004). Perusahaan yang menjadi sampel penelitian ini harus memenuhi beberapa kriteria, yaitu: (1) perusahaan terdaftar di Bursa Efek Indonesia dan menerbitkan laporan keuangan secara lengkap selama tiga tahun berturut-turut (2015-17) (2) perusahaan membagikan deviden kas tahun 2015-2017 dan memiliki kelengkapan data yang digunakan sebagai analisis.

Dengan kriteria tersebut diperoleh jumlah yang memenuhi kriteria sebanyak 37 perusahaan dikalikan selama 3 tahun, maka diperoleh sebanyak 111 perusahaan tahun.

Teknik Pengambilan Sampel. Dalam penelitian ini teknik pengambilan sampel dilakukan dengan metode non probability secara purposive sampling dengan metode pemilihan sampel berdasarkan pertimbangan (judgement sampling) yang merupakan tipe pemilihan sampel secara tidak acak yang informasinya diperoleh dengan menggunakan pertimbangan tertentu (umumnya disesuaikan dengan tujuan atau masalah penelitian) (Indriantoro dan Supomo, 1999). Dalam penelitian ini sampel yang akan diambil adalah 37 perusahaan manufaktur yang terdaftar di BEI periode 20152017.

Sumber Data. Sumber data yang digunakan dalam penelitian ini adalah data sekunder yang merupakan sumber data penelitian yang diperoleh peneliti secara tidak langsung melalui media perantara (diperoleh.dan dicatat oleh pihak lain)
(Indriantoro dan Supomo, 1999). Data dalam penelitian ini diperoleh dari laporan keuangan yang dikeluarkan setiap satu tahun sekali yaitu mulai 31 Desember 2015 sampai dengan 31 Desember 2017 oleh perusahaan manufaktur.

Teknik Analisa Data. Teknik analisa data yang digunakan dalam penelitian ini adalah statistik deskriptif, uji penyimpangan asumsi klasik, analisis jalur (path analysis) dan uji kelayakan model.

\section{HASIL DAN PEMBAHASAN}

Hasil Uji Regresi Linier Berganda. Analisa regresi linier berganda digunakan untuk mengetahui ketergantungan variabel dependen (terkait) dengan satu atau lebih variabel independen (bebas). Selain itu, analisis regresi ini juga menunjukkan arah hubungan antara variabel dependen dengan variabel independen.

Model regresi I menunjukkan hubungan antara profitabilitas dan kebijakan dividen (lihat tabel2), persamaan yang dapat disusun dari model regresi I adalah sebagai berikut :

\section{$\mathbf{Z}=\mathbf{b 0}+\mathbf{b} \mathbf{1 X}$}

$\mathrm{Z}=1,398+0,090 \mathrm{X}$

Keterangan :

Z : Kebijakan Deviden(DPR)

b0 : Konstanta

b1 : Koefisien regresi Profitabilitas (ROE)

$\mathrm{X}$ : Profitabilitas (ROE)

Tabel 2

Analisis Regresi Linier Berganda Model Regresi I Coefficients

\begin{tabular}{|c|c|c|c|c|c|c|}
\hline \multirow{2}{*}{\multicolumn{2}{|c|}{ Model }} & \multicolumn{2}{|c|}{ Unstandardized Coefficients } & \multirow{2}{*}{$\frac{\text { Standardized Coefficients }}{\text { Beta }}$} & \multirow[t]{2}{*}{$\mathrm{t}$} & \multirow[t]{2}{*}{ Sig. } \\
\hline & & $B$ & Std. Error & & & \\
\hline \multirow[t]{2}{*}{1} & (Constant) & 1,398 &, 113 & & 12,418 &, 000 \\
\hline & ROE & ,090 &, 101 & ,085 & ,890 & ,375 \\
\hline
\end{tabular}

a. Dependent Variable: DPR

Sumber : Data diolah, 2019

Tabel 3

Analisis Regresi Linier Berganda Model Regresi II

Coefficients

\begin{tabular}{|c|c|c|c|c|c|c|}
\hline \multirow{2}{*}{\multicolumn{2}{|c|}{ Model }} & \multicolumn{2}{|c|}{ Unstandardized Coefficients } & \multirow{2}{*}{$\begin{array}{c}\text { Standardized Coefficients } \\
\text { Beta }\end{array}$} & \multirow[t]{2}{*}{$\mathrm{T}$} & \multirow[t]{2}{*}{ Sig. } \\
\hline & & B & Std. Error & & & \\
\hline \multirow[t]{3}{*}{1} & (Constant) & $-1,140$ & ,157 & & $-7,259$ & ,000 \\
\hline & ROE & ,877 & 091 & ,651 & 9,616 & ,000 \\
\hline & DPR & ,309 &, 086 & ,243 & 3,587 & ,001 \\
\hline
\end{tabular}

a. Dependent Variable: PBV

Sumber : Sumber : Data diolah, 2019 
Dari persamaan regresi linier berganda model regresi I diatas menunjukan bahwa :

a. nilai konstanta sebesar 1,398 menunjukkan bahwa jika tidak dipengaruhi oleh profitabilitas (ROE) atau dianggap tetap, maka kebijakan deviden adalah sebesar 1,398.

b. b1(nilai koefisien regresi X) sebesar 0,090 menyatakan bahwa setiap kenaikan profitabilitas (ROE) sebesar 1 satuan sedangkan variabel lain tetap (kostan), maka nilai profitabilitas akan mengalami peningkatan sebesar 0,090 satuan

Model regresi II menunjukkan hubungan antara profitabilitas dan kebijakan dividen terhadap nilai perusahaan (lihat tabel3), persamaan yang dapat disusun dari model regresi II adalah sebagai berikut: $\mathbf{v}=\mathbf{b 0}+\mathbf{b} 1 \mathrm{X}+\mathbf{b 2 Z}$

Keterangan :

$\mathrm{Z}$ : Kebijakan Deviden

$\mathrm{Y}$ : Nilai Perusahaan

b0 : Konstanta

b1 : Koefisien regresi Profitabilitas

b2 : Koefisien regresi Profitabilitas

$\mathrm{X}$ : Profitabilitas

Dari persamaan regresi linier berganda pada tabel 3 menunjukan bahwa :

a. nilai konstanta sebesar -1,140 menunjukkan bahwa jika tidak dipengaruhi oleh profitabilitas (ROE) dan nilai perusahan (PBV) atau dianggap tetap, maka kebijakan deviden adalah sebesar 1,140 .

b. b1 (nilai koefisien regresi X) sebesar 0,877 menyatakan bahwa setiap kenaikan profitabilitas (ROE) sebesar 1 satuan sedangkan variabel lain tetap (kostan), maka kebijakan akan mengalami peningkatan sebesar 0,877 satuan. c. b2 (nilai koefisien regresi Y) sebesar 0,309 menyatakan bahwa setiap kenaikan nilai perusahaan sebesar 1 satuan sedangkan variabel lain tetap (kostan), maka kebijakan deviden akan mengalami peningkatan sebesar 0,309 satuan.

Hasil Uji Hipotesis. Hasil uji hipotesis untuk model regresi I menunjukkan bahwa profitabilitas tidak berpengaruh terhadap kebijakan dividen (sig. $>0.05$ ), sedangkan hasil uji hipotesis model regresi II menunjukkan bahwa profitabilitas dan kebijakan dividen berpengaruh positif terhadap nilai perusahaan (sig. <0.05).

Analisa Jalur. Berikut ini adalah hasil analisis jalur untuk mendapatkan pengaruh langsung dan tidak langsung antara profitabilitas terhadap nilai perusahaan.

Pengaruh Langsung. Pengaruh langsung profitabilitas terhadap nilai perusahaan dapat dilihat pada gambar 2, yaitu sebesar 0,877 .

Pengaruh Tidak Langsung. Pengaruh tidak langsung (indirect effect) profitabilitas (ROE) terhadap nilai perusahaan (PBV) melalui kebijakan deviden (DPR) juga tampak pada gambar 2.

Besarnya pengaruh tidak langsung profitabilitas (X) terhadap Nilai perusahaan (Y) melalui kebijakan dividen $(Z)$ dapat diperoleh dari perkalian antara nilai beta $X$ terhadap Y dengan nilai beta Y terhadap $Z$ yaitu $0,090 \times 0,309=0,028$.

Pengaruh intervening yang ditunjukkan oleh perkalian $0,651 \times 0,243=0,158$ signifikan atau tidak diuji dengan sobel test sebagai berikut:

$$
\begin{aligned}
& \mathrm{Sp} 2 \mathrm{p} 3=\sqrt{p 3^{2} S p 2^{2}+p 2^{2} S p 3^{2}+S p 2^{2} S p 3^{2}} \\
& \sqrt{(0,309)^{2}(1} \sqrt{(0,000973)+(0,000056)+(0,000075)} \\
& =\sqrt{0,011}=0,0331
\end{aligned}
$$

\section{Gambar 2}

Pengaruh Langsung dan Tidak Langsung

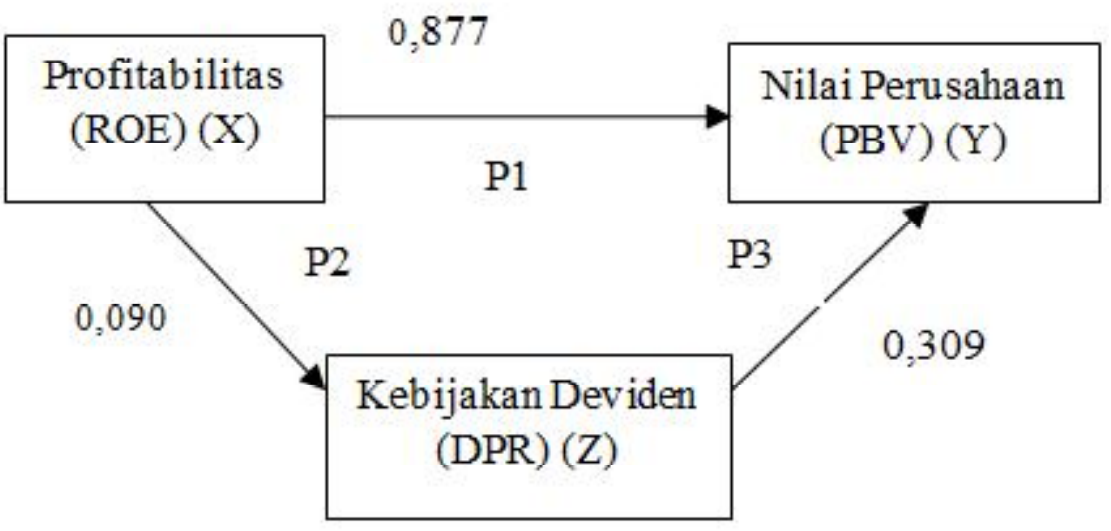


Berdasarkan hasil Sp2p3 dapat dihitung nilai zstatistik pengaruh intervening dengan rumus sebagai berikut :

$\mathrm{Z}=\frac{p 2 p 3}{\operatorname{Sp1p3}}=\frac{0,090 \times 0,309}{0,3179}=\frac{0,02781}{0,3179}=0,8401$

Dari hasil diatas nilai $z$ hitung 0,8401 lebih kecil dari $\mathrm{z}$ tabel dengan tingkat signifikan 0,05 yaitu sebesar 1,96. maka dapat disimpulkan bahwa koefisien intervening 0,028 tidak signifikan.

Pengaruh Total. Pengaruh total dapat dihitung dengan menjumlahkan pengaruh langsung dan tidak langsung, sebagai berikut: $0,309+0,158=0,467$.

Pembahasan. Berdasarkan hasil pengujian, maka diperoleh hasil bahwa pada model regresi I profitabilitas tidak berpengaruh terhadap kebijakan deviden. Secara teori besarnya profitabilitas akan mendorong manajemen untuk membagikan dividen. Hal ini merupakan hal yang menguntungkan bagi kedua belah pihak (manajemen dan investor), karena berdasarkan teori agensi dan sinyal pembagian dividen mampu mengurangi konflik keagenan, sekaligus memberikan sinyal positif terhadap investor. Berdasarkan teori bird in hand, maka investor juga cenderung menyukai dividen tunai.

Sayangnya, hasil penelitian ini tidak memberikan hasil yang sama. Profitabilitas tidak mempengaruhi besarnya dividen tunai yang dibagikan. Hal ini dapat disebabkan oleh beberapa hal. Yang pertama adalah kondisi perusahaan manufaktur yang beragam. Perusahaan manufaktur terdiri dari beberapa jenis perusahaan yang memiliki rentang sangat panjang, dengan karakter yang beragam. Karakter ini sangat mungkin terbawa dalam kebijakan dividen masing-masing jenis industry. Sehingga dalam penelitian ini perbedaan karakter kebijakan dividen tidak terbaca dengan baik.

Alasan kedua adalah adanya faktor lain yang mempengaruhi pembagian dividen, diantaranya adalah arus kas dan struktur modal. Kedua item ini sangat mempengaruhi kebijakan manajemen dalam membagikan dividen. Ada tidaknya kas menjadi unsur utama dalam pembagian dividen tunai. Demikian juga terkait struktur modal, jumlah hutang yang tinggi akan mengakibatkan perusahaan lebih berkonsentrasi untuk memenuhi kewajiban pembayaran bunga daripada membagikan dividen.
Pada model regresi II, semua hipotesis dapat terpenuhi, yaitu profitabilitas dan kebijakan dividen berpengaruh terhadap nilai perusahaan. Dari sisi profitabilitas, hasil penelitian ini sesuai dengan konsep teori signalling yang menyatakan bahwa ketika investor menerima informasi yang baik (good news) terhadap kinerja suatu perusahaan, maka inverstor akan bereaksi yaitu membeli saham. Semakin banyak investor yang tertarik maka harga saham yang tercipta akan meningkat, dan meningkatnya harga saham membuat nilai perusahaan akan meningkat pula (Brigham,2004).

Demikian pula dari sisi kebijakan dividen, hasil penelitian ini sesuai dengan teoribird in the hand yang menyatakan bahwa sesungguhnya investor jauh lebih menghargai pendapatan yang diharapkan dari dividen daripada pendapatan yang diharapkan dari keuntungan modal karena komponan hasil dividen.

\section{PENUTUP}

Kesimpulan. Berdasarkan hasil penelitian dan pembahasan pada bab sebelumnya, maka dapat disimpulkan bahwa:

1. Profitabilitas $(X)$ tidak berpengaruh terhadap kebijakan deviden (Z) pada perusahaan manufaktur yang terdaftar pada BEI periode 2015-2017

2. Profitabilitas $(X)$ berpengaruh terhadap nilai perusahaan (Y) pada perusahaan manufaktur yang terdaftar pada BEI periode 2015-2017

3. Kebijakan deviden $(\mathrm{Z})$ berpengaruh terhadap nilai perusahaan (Y) pada perusahaan manufaktur yang terdaftar pada BEI periode 2015-2017

4. Kebijakan deviden (Z) tidak mampu memediasi secara signifikan hubungan antara profitabilitas (X) terhadap nilai perusahaan (Y) pada perusahaan manufaktur yang terdaftar pada BEI periode 2015-2017

Saran. Berdasarkan hasil dan pembahasan, maka dapat disimpulkan bahwa penelitian ini memiliki beberapa keterbatasa, berdasarkan keterbatasan tersebut, maka saran yang dapat diberikan antara lain:

1. Bagi Investor, sejauh ini profitabilitas dan kebijakan dividen masih merupakan predictor terbaik untuk nilai perusahaan. Profitabilitas 
memberikan jaminan akan berkembangnya perusahaan, sementara kebijakan dividen memberikan jaminan peningkatan kemakmuran investor

2. Bagi penelitian selanjutnya, penelitian ini hanya menggunakan profitabilitas sebagai variabel eksogen tunggal yang menyebabkan fungsi kebijakan dividen menjadi kurang terlihat, sehingga pada penelitian berikutnya dapat ditambahkan variabel eksogen yang lain seperti arus kas dan struktur modal.

\section{DAFTAR PUSTAKA}

Aditya \& Supriyono. Pengaruh Profitabilitas Dan Kepemilikan Institusional Terhadap Nilai Perusahaan Dengan Kebijakan Dividen Sebagai Variabel Intervening Pada Perusahaan Manufaktur yang terdaftar di Bursa Efek Indonesia Periode 2010-2014. Universitas Muhammadiyah, Yogyakarta. Vol.6, No. 1. 2015.

Alamsyah, Sustari. Pengaruh Profitabilitas terhadap Nilai Perusahaan, Relevansi Nilai Informasi Akuntansi, Keputusan Investasi, Kebijakan Dividen sebagai Variabel Intervening. Competitive, Vol.1, No.1, 2017.

Arindita \& R. Djoko Sampurno. Analisis Pengaruh Struktur Modal, Profitabilitas, Kebijakan Deviden dan Size Terhadap Nilai Perusahaan. Universitas Diponegoro, Semarang. Vol.4, No.2, 2015.

Azhar, Zulfa Afifatul, dkk. Pengaruh Profitabilitas terhadap Nilai Perusahaan Melalui Kebijakan Deviden Sebagai Variabel Intervening. Universitas Diponegoro, Semarang, Vol. 7, No. 4, 2018.

Brigham. E, \& Houston, J. Fundamentals of Financial Management. Edisi 8. Boston : ISBN. 2015.

Dewi \& Wirajaya Ary. Pengaruh Struktur Modal, Profitabilitas dan Ukuran Perusahaan pada Nilai Perusahaan. Universitas Udayana, Bali. ISSN:2302-8556. 2013.

Fakhrudin \& Hadiyanto. Perangkat dan Model Analisis Investasi di Pasar Modal, Edisi Pertama. Elex Medi Komputindo : Jakarta. 2001.

Gozhali, Imam. Aplikasi Analisis Multivariate dengan Program SPSS. Badan Penerbit Universitas Diponegoro, Semarang. 2005.
Gozhali, Imam. Aplikasi Analisis Multivariate dengan Program SPSS. Badan Penerbit Universitas Diponegoro, Semarang. 2011.

Harmono. Manajermen Keuangan. PT Bumi Aksara : Jakarta. 2009.

http://sobatbaru.blogspot.com/2010/05/nilaiperusahaan.html. 4:34, Mei 2010.

http://www.kemenperin.go.id/artikel/18920/ Kawasan-Industri-di-Gresik-Berpotensi-SerapInvestasi-Rp-83,2-Triliun

https://www.bps.go.id/pressrelease/2018/02/01/ 1479/pertumbuhan-produksi-industrimanufaktur-besar-dan-sedang-triwulan-ivtahun-2017-naik-sebesar-5-15-persen-danpertumbuhan-produksi-industri-manufakturmikro-dan-kecil-triwulan-iv-2017-naik-sebesar4-59-persen.html. Februari 2018.

https://bisnis.tempo.co/read/47018/penerbitansaham-tanpa-nilai-nominal-diusulkan-dalam-uupasar-modal. 17:50.Agustus 2004.

https://dosen.perbanas.id/metode-penilaian-nilaiperusahaan/. September 2016

Husnan, Suad. Manajemen Keuangan : Teori dan Penerapan (Keputusan Jangka Panjang). Buku 1. Yogyakarta : BPFE. 1996.

Indriantoro \& Supomo. Metodologi Penelitian Bisnis Untuk Akuntansi Dan Manajemen, Edisi Pertama. BPFE : Yogyakarta. 1999.

Indriawati, dkk. Pengaruh Profitabilitas, Кериtusan Investasi dan Pertumbuhan Perusahaan Terhadap Nilai Perusahaan dengan Kebijakan Deviden Sebagai Variabel Intervening. Universitas Pandanaran, Semarang. Journalof Accounting. 2018.

Jogiyanto, Hartono. Teori Portofolio dan Analisis Investasi. Edisi Kedua. Yogyakarta : BPFE. 2000.

Kherismawati,dkk. Profitabilitas dan Leverage Sebagai Prediktor Kebijakan Deviden dan Nilai Perusahaan. Universitas Warmadewa, Denpasar. Vol.3, No.1, Maret 2017.

Khomsatun, dkk. Pengaruh Profitabilitas Terhadap Nilai Perusahaan Dengan Kebijakan Deviden Sebagai Variabel Intervening. Universitas Islam Malang. Fakultas Ekonomi dan Bisnis Unima.2018.

Mahendra Dj, Alfredo, dkk. Pengaruh Kinerja Keuangan Terhadap Nilai Perusahaan Pada Perusahaan Manufaktur Di Bursa Efek Indonesia. Universitas Udayana, Denpasar, Vol. 6, No. 2, Agustus 2012.

Mardiyati, dkk. Pengaruh Kebijakan Deviden, 
Kebijakan Hutang dan Profitabilitas Terhadap Nilai Perusahaan. Universitas Negeri Jakarta, Vol.3, No.1.2012.

Nofrita, Ria. Pengaruh Profitabilitas terhadap Nilai Perusahaan dengan Kebijakan Deviden sebagai Variabel Intervening. Jurnal Penelitian Universitas Negeri Padang, Padang, Februari 2013. Tesis

Nurhayati, Marfizatun. Profitabilitas, Likuiditas dan Ukuran Perusahaan Pengaruhnya Terhadap Kebijakan Deviden dan Nilai Perusahaan. Universitas Mercu Buana: Jakarta. Vol. 5, No. 2, Juni 2013.

Pasaribu, Mirry Yunianti, dkk. Pengaruh struktur Modal, Struktur Kepemilikan dan Profitabilitas Terhadap Nilai Perusahaan Pada Perusahaan Sektor Industri Dasar dan Kimia yang Terdafta di BEI tahun 20112014. Universitas Brawijaya, Malang, Vol.35, No. 1, Juni 2016.

Permanasari, Wien Ika. Pengaruh kepemilikan Manajemen, Kepemilikan Intitusional dan Corporate Social Responsibility Terhadap Nilai Perusahaan. Universitas Diponegoro, Semarang.2010. Tesis

Ramadhani, Annisa Ikka. Pengaruh Keputusan Investasi, Keputusan Pendanaan dan
Kebijakan Deviden Terhadap Nilai Perusahaan. STIE Perbanas, Surabaya. 2018 Sartono, R. Agus. Manajemen Keuangan Teori dan Aplikasi. Yogyakarta : BPFE. 2010

Sartono, R. Agus. Manajemen Keuangan Teori dan Aplikasi. Yogyakarta : BPFE. 2014.

Sujoko \& Soebiantoro. Pengaruh Struktur Kepemilikan Saham, Leverage, Faktor Interen dan Faktor Eksteren Terhadap Nilai Perusahaan. Jurnal Manajemen dan Kewirausahaan, Vol. 9, No.1, Maret 2007.

Taslim, Fadli Ali. Pengaruh Rasio Likuiditas, Aktivitas, Profitabilitas Terhadap Nilai Perusahaan dengan Kebijakan Deviden Sebagai Variabel Intervening. Jurnal Equilibrium, Vol.X, No.1, Juni 2016.

Tryfino. Investasi Saham. Cetakan Keempat. TransMedia: Jakarta.2009.

Weston \& Coupeland. Manajemen Keuangan. Jilid II. Edisi Kesembilanbelas. Erlangga : Jakarta. 1997.

Wulansari, Kartika Hadiyanti. Pengaruh Profitabilitas terhadap Nilai Perusahaan dengan Kebijakan Deviden Sebagai Variabel Intervening pada Perusahaan LQ45 diBursa Efek Indonesia. STIE Perbanas, Surabaya. 2015. Tesis. 